\title{
Optimization of Enhancement of Lecturer Professional Commitment using Path Analysis and Sitorem Method
}

\author{
Sri Setyaningsih, Muhamad Saad Nurul Ishlah, Soewarto Hardhienata
}

\begin{abstract}
Professional commitment of lecturers is an important element in the achievement of educational goals in universities, but from the initial survey at Pakuan University, it was shown that the current situation is still not as expected. Therefore, Professional commit-ment of lecturers is interesting to be studied.

Based on the above background, the purpose of this research is to seek efforts to increase the professional commitment of lectures through the development of empowerment and trust. The study was conducted using path analysis method to determine whether other variables, namely empowerment and trust, had a positive effect towards professional commitment of lectures. The population in this research is permanent lecturer at Pakuan Uni-versity with functional position of Asisten Ahli up to Lektor Kepala amounting to 337 people with sample determined from popula-tion randomly amounted to 135 people. To obtain optimal results in an effort to increase the professional commitment of lecturers used Sitorem Method.

The results showed that: (a) there is a positive direct influence of empowerment to organizational commitment, $(b)$ there is a posi-tive direct effect of empowerment to organizational commitment, (c) there is a direct positive influence of trust on organizational commitment.

From Sitorem's analysis it is concluded that there is a preserved indicator, i.e. open communication, readiness to accept occupation risks, sooth, and improvement desire, and indicators that need to be improved in order of priority of treatment is as follows: 1. au-thority, 2. discretion, 3. creativity and innovation, 4. confidence in ability and strength, 5. openness, 6. partnership strength, 7. awareness, 8. dedication and devotion, 9. consistency, 10. skills development.
\end{abstract}

Index Terms: professional commitment of lectures, empowerment, trust, path analysis, sitorem method

\section{INTRODUCTION}

Lecturers as professional educators have a good image if it can be an example for the surrounding community. Lecturers are also required to provide knowledge, develop and improve the quality of the organization and professionalism of work. In addition, lecturers should be able to improve the qualifications and stratum of lecturers education, apply academic culture, and willing to work to improve the welfare of lecturers and conduct activities on the community. Therefore, lecturers are expected to have a good standard of

Revised Manuscript Received on April 25, 2019.

Sri Setyaningsih, Department of Computer Science \& Postgraduate Program, Pakuan University, Indonesia.

Muhamad Saad Nurul Ishlah, Department of Computer Science, Pakuan University, Indonesia.

Soewarto Hardinata, Department of Computer Science, Pakuan University, Indonesia. quality improvement competence in order to implement Tri Dharma Perguruan Tinggi with good category. Pakuan University (UNPAK) is an institution of higher education established with the aim to produce graduates who are superior, independent, and have good character. Pakuan University strives to always anticipate changes. The changes are meant to make innovations so that UNPAK can compete with other universities, especially in West Java. The need for innova-tion is an important strategy for a college institution in order that the system in it can run effectively.

The above policy supports the need for innovation that is ori-ented towards improving the quality of the higher education process. In order that UNPAK can survive and develop on an ongoing basis, efforts should be made. Among them by way of strategies to empower the lecturers both lecturers status civil servants (PNS) who seconded as well as the status as a perma-nent lecturer of the foundation.

Policies that concern the management of UNPAK include the lecturers who are one of the main resources in higher education institutions. The resources must be maximally empowered in order to make a real contribution in realizing the vision of UN-PAK institution, which is to produce graduates who are superior, independent, and have good character and also have the basic characteristics of life of silih asih, silih asah and silih asuh. The achievement of UNPAK vision needs to be supported by vari-ous aspects, such as high professional commitment, improved quality resources, good empowerment in all sectors including lecturer empowerment, high performance, good academic cul-ture, and high trust of institutions.

The effort to build commitment is described as an effort to build a long-term relationship and stay with the institution. It is manifested in the form of attitudes and behaviors, such as the desire to know and engage in institutions, as well as how psy-chologically lecturers have feelings of loyalty, affection, warmth, ownership, pride, joy and happiness for having worked at UNPAK. Lecturer profession commitment is needed in the implementation of the autonomy and development of universi-ties because with a high professional commitment, the lecturer will be able to run various roles so that the activity plan and the continuous development plan made by the college can be run well. Commitment also relates to beliefs, trusting in truth, strength, belonging and strong support for the value and goals a person wants to achieve his wishes. Lecturers as educators use professional commitment as a philosophy or dedication in work. Therefore, the professional lecturer will be a good lecturer or 'the good teacher' who has the characteristics: 
intelligent, has a good personality, respects others, is attractive in appearance, and has a noble character.

Commitment of lecturer profession is not only seen from the productivity of university tridharma implementation, but norma-tively can also be seen from the level of education and func-tional position of lecturers achieved. To that end, the need for cooperation with institutions that handle human resource man-agement (HR) in college. Rector's report shows that in UNPAK there are still some lecturers who are in undergraduate education. This indicates that the commitment of lecturers to improve the sciences in the implementation of teaching duties as stipulated in Law Number 14 Year 2005 on Teachers and Lecturers Arti-cle 46, paragraph 2 that lecturers have minimum academic qual-ifications of master's degree graduates for diploma or under-graduate program, as well as graduate doctoral programs for graduate programs have not been met. The existence of high professional commitment is expected to make the lecturers do everything good so that the vision of UNPAK can be achieved as predetermined. A good profession commitment can be meas-ured by willingness, loyalty, pride, loyalty, and integrity as a professional lecturer.

Lecturers at UNPAK are required to have expertise in their re-spective subjects and are expected to have full submission and dedication in achieving the vision of UNPAK which implies toward responsibility to self and to society. The condition of lecturer at UNPAK based on functional position in 2012 shows that $21 \%$ of lecturers have not functional position, $18 \%$ in the position of expert assistant, and lecturer with title of professor is still very minimal. The functional position of the lecturer is basically an acknowledgment, appreciation and trust on the competence, performance, integrity and responsibility in the execution of the task, and the lecturer's manners in carrying out the duties of Tridharma.

Efforts to increase the role of lecturers in UNPAK to conduct research is still felt less. In the Rector's report in 2013 it was stated that the lecturers who received the research grant compet-ed only 13 titles, consisting of 10 titles by FMIPA lecturers, one title by FKIP lecturer, one title by the lecturer of Engineering, and one title by lecturer of Graduate Program. This does not reflect the activities and interest of the lecturers to research be-cause as mentioned above only a few faculties are involved in the research, especially the research that is financed by the Higher Education. Efforts to increase the role of lecturers in UNPAK to conduct research is still felt less. In the Rector's re-port in 2013 it was stated that the lecturers who received the research grant competed only 13 titles, consisting of 10 titles by FMIPA lecturers, one title by FKIP lecturer, one title by the lec-turer of Engineering, and one title by lecturer of Graduate Pro-gram. This does not reflect the activities and interest of the lec-turers to research because as mentioned above only a few facul-ties are involved in the research, especially the research that is financed by the Higher Education.

Law No.14 Year 2005 on Teachers and Lecturers Article 1 , paragraph 2, states that lecturers are professional educators and scientists with the primary task of transforming, developing and disseminating science, technology and the arts through educa-tion, research, and devotion to community. This regulation em-phasizes the profession of lecturers is not only a professional educator at the university, but simultaneously a lecturer as well as a scientist and a pioneer in community service. Commitment of lecturer profession to society service which currently con-ducted by lecturer of Unpak still not maximal. It is seen that in 2013 the lecturers of Unpak only get 6 IPTEKS grants for the Community (IbM), and only produce 1 grant of Lesson Study from Higher Education. In 2014 there is even a decrease in the number of grants for all Unpak. Decrease or lack of research results and community service that will impact on the publica-tion of journals that have an impact on the delayed increase in functional positions of lecturers. This indicates that the profes-sional commitment of the lecturer to Tridharma research is still lacking. Therefore, the lecturer should be committed to his pro-fession to improve the ability to produce scientific work through journals and books, so that the resulting scientific work in the form of a research report out of standing. It is a hallmark of academic culture that must be owned by lecturers.

Based on the above background, the purpose of this research is to seek efforts to increase the professional commitment of lec-turers through the development of empowerment and trust. To know the influence of the variables studied used path analysis, while to obtain optimal solution used analysis with the method of Sitorem.

\section{THEORETICAL REVIEW}

\section{A Professional Commitment}

Conceptually, commitment is defined as the loyalty and integrity of a lecturer in performing the task. One of the definitions of commitment that emphasizes loyalty is expressed by Luthans [22] who views commitment in the context of a person's loyalty to his or her work and a committed individual will continue to strive to become a member of that profession. John W. Newstorm [14] defines commitment as the level of employee engagement with his organization and employee involvement is demonstrated by the activities undertaken for the organization. In the context of educational philosophy, Raymond B.Fox [22] considers that lecturers or employees who are committed to their profession one of them can be shown from consistency in the work. According to R. Kannan and S. Muthu Permal [16] "Commitment to the profession, the person is expected to uphold certain ethics and values to fulfill his commitment to that profession.

Furthermore, Lawrence J. Saha and A. Gary Dworkin [23] divide five types of professional commitment, namely (1) teacher commitment to the school, (2) teacher commitment to the student, (3) teacher commitment to the teaching work , (4) teacher commitment to the profession, (5) teacher commitment to a body of knowledge, attitudes and skills.

Based on the above conceptual descriptions, it can be synthesized that professional commitment is the loyalty, involvement, and integrity of a lecturer in performing tasks based on skills, expertise and responsibility, with indicators: (1) seriousness in carrying out responsibilities, (2) consistency in carrying out tasks on the basis of expertise, (3) desire for scientific improvement, (4) skill or skill development, and (5) dedication and dedication to the institution. 


\section{B Empowerment}

According to John Schermerhorn et.al. [26] empowerment means that a manager employs employees so they can work independently to complete their tasks. In the implementation of empowerment required a high level of trust, openness and integrity in the top management. Empowerment according to Robbins in Arman Kanooni [15] is a concept of participative management, delegate, and giving authority to the lower level employees to make and make decisions.

Heinz Weihrich and Harold Koontz [12] state that Empowerment means that every employee, manager, or team at every level within the organization is empowered to make decisions without asking permission from their superiors. This theory emphasizes that every lecturer must have the competence so that in decision making can be done properly because he understands.

Jennifer M. George and Gareth R. Jones [20] said that employee empowerment is one of the efforts and strategies to provide opportunities to employees and responsible for its performance. While Adrian Furnham [1] states, empowerment requires authority and responsibility. Nancy Langton and Stephen P. Robbins [20] define empowerment leading to the freedom and ability of employees in making decisions, as well as in enforcing work commitments. Khan [18] argues that essentially empowerment is a sustainable interpersonal relationship that fosters mutual trust between employees and leaders.

Based on the study of the theories above can be synthesized that empowerment or empowerment is the authorization and responsibility of the leadership to the employee to perform the tasks creatively and innovatively in responding to various dynamic changes according to the ability it has with indicators: (1) the provision of responsibility (2) discretion in completion of tasks, (3) authority in decision making, (4) creativity and innovation in responding to change, and (5) open communication between employees and leaders.

\section{Trust}

In general, according to Zaki Malik and Athman Bouguettaya [37], beliefs concerning the psychological relationship between the two parties. Trust is something that is attached to one's character, ability, or strength. Nancy Langton and Stephen Robbins [20], said that believing is something in which a person has self-confidence as a positive expectation of believing that it will not take the form of an opportunit.

Colquit et.al. [4] defines, trust as a willingness to be sensitive to authority based on positive expectations about actions performed by the authorities. If a person believes, then that person will gladly accept whatever risk will be earned. Fukuyama [7] explains that trust is a hope that arises in society, such as order, honesty, cooperative behavior, and become part of society norm. Pamela Shockley-Zalabak et.al. [30] classify five key dimensions of trust as follows (1) Organizational competence, leadership ability, strategy, decision making, quality, and environment. (2) Openness and honesty and organizational communication. (3) Organizational awareness of employees / stakeholders, including listening, ideas, problems, needs, communication with leaders, duties and responsibilities, policies, and exercises. (4) Organizational religiosity, including commitment, follow-up, steadiness, consistency of behavior, and consistency of task description. (5) Organizational identification.

Based on the above concept study, it can be synthesized that trust or trust is an employee's belief in the leadership and among employees in the work environment based on character, ability, and strength in achieving organizational goals, with indicators: (1) openness and honesty, (2) ) awareness of employees, (3) partnership strength, (4) readiness to accept occupational risks, and (5) confidence in ability and strength.

\section{THEORETICAL FRAMEWORK AND RESEARCH HYPOTHESIS}

\section{A Empowerment and Professional Commitment}

According to John R. Schermerhorn [33] empowerment allows individuals or groups to make decisions that can affect their attitude or work. Andrian Furnham [1] asserted, empowerment requires authority and responsibility. This implies that the lecturer should be given the authority to take decisions if they feel right, the controls in the work, ready to accept the risks and learn from any mistakes made. From the statement it is clear that empowerment requires the commitment of lecturers to have high loyalty, ready to be involved in carrying out tasks on the basis of skills, expertise, and responsibilities that must be committed.

Nancy Langton and Stephen P. Robbins [20] stated that empowerment leads to the freedom and ability of employees in making decisions, as well as in enforcing work commitments. It appears that empowerment is related to an employee's commitment. Commitment based on the duty of the profession chosen by a lecturer is not merely a part of the college institution that runs the college tridharma alone, but more than that. From the statement, the empowered lecturer will be willing to raise his commitment to accelerate the achievement of the institution's vision. With the commitment of the profession, as written Laurie J. Mullins [21], which is through three pillars of commitment, including: (1) A sense of belonging to the organization, as the basis of building loyalty to the organization, such as: informed, involved, sharing in success, (2) A sense of excitement in job, a feeling of pleasure working out of motivation, embodied in pride, trust, accountability for result, and (3) Confidence in management, meaning trust in organizational management because feelings are respected by leadership , which is shown in: authority, dedication, competence.

One of the implications of the above description is if empowered then the lecturer will have a high profession commitment as a tool to assess lecturer's responsibility at the institution. Based on the above theory, it can be suspected that there is a direct positive influence of lecturers' empowerment of professional commitment.

\section{B Trust and Professional Commitment}

Nancy Langton and Stephen Robbins explained that trust is a positive expectation (believe) that there will be no opportunism. 
From the theory can be interpreted that a lecturer should act positive, not merely acting for selfishness, but also attention to the needs of others or institutions. This can be done through: integrity, competence, consistency, loyalty, and openness. Affirmed by Colquit et.al. [4] that trust is a willingness to be sensitive to authority based on positive expectations about the actions of authority and desire. The existence of the trust given will make the lecturer work with sincere, willing, and dare to accept the challenges given. The same opinion is expressed by Pamela S. Shockley [30] that the trust given to the employee leadership in an organization will impact on the high loyalty. This means, if the lecturer is given the trust then the lecturer will really maintain and maintain its commitment in achieving the educational objectives.

On the basis of the above theory, it can be expected that there is a direct positive influence of trust on professional commitment.

\section{Empowerment and Trust}

Employee empowerment according to Zaki Malik and Athman Bouguettaya [37] is a strategy to create employees who excel at work. At an individual level trust affects the willingness to cooperate and make organizational change. The theory sees empowered lecturers who feel important, happy and challenged by their work, and are part of a team. This is according to Fred Luthans [5] if this is applied to lecturers, then the leadership can do various ways to use lecturer's initiative, do it yourself as instructed, lecturer not only given the authority but also given the flexibility and given the opportunity to implement it.

According Khan [18] empowerment is basically a continuous interpersonal relationship that fosters mutual trust between employees and leaders. This shows that if there is no mutual trust between subordinates and leaders, it can lead to role conflict that has an impact on employee behavior, such as decreasing job satisfaction, employee movement, decreasing performance, and decreasing trust in the institution. As a result, empowered lecturers will trust each other, openness, need to be involved, give lecturers the opportunity to solve their own problems, feel welcome and respected, and work according to their abilities. The treatment received by the lecturer above will gradually bind the lecturer to work optimally.

On the basis of the above theory, it can be expected that there is a direct positive influence of empowerment of trusts.

\section{Research Hypothesis}

Starting from the theoretical framework above, the hypotheses of research are derived as follows :

a. Empowerment has a direct positive effect on professional commitment.

b. Trust has a direct positive effect on professional commitment.

c. Empowerment has a direct positive effect on trust.

\section{RESEARCH METHODOLOGY}

The population in this research is permanent lecturer at Pakuan University with functional position of Asisten Ahli up to Lektor Kepala amounting to 337 people with sample determined from population randomly amounted to 135 people.

This research uses quantitative approach through path analysis with survey methods to find out the effects of empowerment and trust toward the professional commitment of lecturers. First, the research instrument was tested using the Pearson Product Moment formula to test the validity of the instruments to be used. Then the instrument reliability testing was done using the Alpha Cronbach formula. After that, a statistical hypothesis test is conducted to find out the direct positive relationship of the variables studied.

Statistical hypothesis tested in this research are:

a. The first hypothesis examines the direct effect of empowerment on professional commitment

$\mathrm{H} 0: \beta y 1 \leq 0$

$\mathrm{H} 1: \beta y 1>0$

b. The second hypothesis examines the direct effect of trust on professional commitment

H0: $\beta y 2 \leq 0$

$\mathrm{H} 1: \beta \mathrm{y} 2>0$

c. The third hypothesis examines the direct effect of empowerment on trust

H0: $\beta \mathrm{y} 3 \leq 0$

$\mathrm{H} 1: \beta \mathrm{y} 3>0$

To obtain optimal results in an effort to increase the professional commitment of lecturers used Sitorem Method by Hardhienata (2017:6). Sitorem stands for Scientific Identification Theory to Conduct Operation Research in Education Management. Sitorem analysis is used to determine the Recommendations and Priority Order for Improvement Management. There are 3 (three) criteria used, namely: the strength of influence between the independent variables and the dependent variable, the order of priority indicators of the variables studied, and the indicator values obtained from the results of research in the field.

The strength of influence between independent variables and dependent variables is obtained from the results of data analysis using correlation statistical methods. While the order of priority indicators is prepared based on input from expert opinion and analysis from researchers. Indicator values are obtained from the calculation of data from the results of the research respondents.

\section{RESULTS AND DISCUSSION}

Description of the data presented in this section includes the data of professional commitment (Y) variable which is endogenous variable and trust variable (X2) as intervening variable and empowerment variable (X1) as exogenous variable. 
Table 1

Recapitulation of the Data Description of Variable $X_{1}, X_{2}$, and $Y$

\begin{tabular}{|l|l|c|c|c|c|c|c|c|}
\hline No & \multicolumn{1}{|c|}{ Variabel } & $X_{\min }$ & $X_{\max }$ & Range & Mean & $\begin{array}{c}\text { St } \\
\text { Dev }\end{array}$ & Median & Modus \\
\hline 1. & $\begin{array}{l}\text { Professional } \\
\text { Committment }\end{array}$ & 90 & 174 & 84 & 142.99 & 15.17 & 143.29 & 142.53 \\
\hline 2. & Empowerment & 69 & 204 & 135 & 141.22 & 19.97 & 141.77 & 141.50 \\
\hline 3. & Trust & 106 & 200 & 94 & 159.76 & 17.90 & 158.75 & 157.50 \\
\hline
\end{tabular}

The sub-structural equation becomes

$Y=\rho_{\mathrm{y} 1} X_{1}+\rho_{\mathrm{y} 2} X_{2}+E_{y}=0.34 X_{1}+0.19 X_{2}+0.57$

$\mathrm{X} 2=\mathrm{Bx} .1 \mathrm{X}_{1}+\mathrm{E}_{\mathrm{X} 2}=0.39 \mathrm{X}_{1}+0.58$

The problem constellation can be described as follows :

Prior to the path analysis, the data must meet some statistical test requirements, namely: (1) Error Normality Test, and (2) Significance Test and Linearity of Regression Coefficient.

Table 2

Summary of Normality Error Test

\begin{tabular}{|c|c|c|c|c|c|c|}
\hline \multirow{2}{*}{ Nr. } & \multirow{2}{*}{ Estimated error } & \multirow{2}{*}{$n$} & \multirow[b]{2}{*}{ Lesalusteded } & \multicolumn{2}{|c|}{$\mathrm{L}_{\text {tabla }}$} & \multirow{2}{*}{ Decision } \\
\hline & & & & $a=0,05$ & $a=0,01$ & \\
\hline 1. & Yover $X_{1}$ & 135 & 0.06 & 0.08 & 0.09 & Normal \\
\hline 2. & Yover $X_{2}$ & 135 & 0.06 & 0.08 & 0.09 & Normal \\
\hline 3. & $X_{2}$ over $X_{1}$ & 135 & 0.04 & 0.08 & 0.09 & Normal \\
\hline
\end{tabular}

In accordance with the above description, the normality requirements for estimated error have been met.

Table 3

Summary of Linearity Test Results Regression Model

\begin{tabular}{|c|c|c|c|c|c|}
\hline Nr. & $\begin{array}{c}\text { Inter-variable } \\
\text { Relationship } \\
\text { Model }\end{array}$ & F-calculated & $\begin{array}{c}\mathrm{F}=\text { table } \\
(\mathrm{a}=0,05)\end{array}$ & $\begin{array}{c}\mathrm{F}=\text { table } \\
(\mathrm{a}=\mathbf{0 , 0 1})\end{array}$ & $\begin{array}{c}\text { Liniarity } \\
\text { pattern test } \\
\text { results }\end{array}$ \\
\hline 1. & Y over $\mathrm{X}_{1}$ & 0.92 & 1.49 & 1.77 & Linear \\
\hline 2. & Y over $\mathrm{X}_{2}$ & 1.04 & 1.49 & 1.77 & Linear \\
\hline 3. & $\mathrm{X}_{2}$ over $\mathrm{X}_{1}$ & 1.45 & 1.49 & 1.77 & Linear \\
\hline
\end{tabular}

From the above table it can be concluded that there is a positive direct effect of empowerment of professional commitment, positive direct influence of trust on professional commitment, and direct positive influence of empowerment of trust.

\section{Model Testing}

Prior to testing the causality model by using path analysis, it is first necessary data of research that has been tested and meet all the requirements. One important requirement that must be met is a significant correlation between related variables.

Sub structural Equations

$Y=\rho_{\mathrm{y} 1} X_{1}+\rho_{\mathrm{y} 2} X_{2}+E_{y}$

$\mathrm{X}_{2}=\rho_{\mathrm{X} 1} \mathrm{X}_{1}+\mathrm{E}_{\mathrm{X} 2}$

Hypothesis testing

The path coefficient value $(\rho)$ is calculated using regression analysis implemented in the SPSS statistical program. A summary of the overall hypothesis testing results is summarized in Table 4 below.

Table 4 : Recapitulation of Hypothesis Testing Results

\begin{tabular}{|c|c|c|c|l|}
\hline Variable & Path Coeff. & $\mathrm{T}_{\text {Calculated }}$ & $\mathrm{T}_{\text {Table }}$ & \multicolumn{1}{|c|}{ Testing Decision } \\
\hline $\begin{array}{c}\mathrm{X}_{1} \\
\text { towards } \\
\mathrm{Y}\end{array}$ & $\rho_{\mathrm{y} 1}=0,34$ & 4,35 & 1,97 & $\begin{array}{l}\mathrm{H}_{0} \text { rejected, } \mathrm{H}_{1} \text { accepted, there is a direct } \\
\text { positive influence of empowerment } \\
\text { towards professional commitment }\end{array}$ \\
\hline $\begin{array}{c}\mathrm{X}_{2} \\
\text { towards } \\
\mathrm{Y}\end{array}$ & $\rho_{\mathrm{y} 2}=0,19$ & 2,12 & 1,97 & $\begin{array}{l}\mathrm{H}_{0} \text { rejected, } \mathrm{H}_{1} \text { accepted, there is a direct } \\
\text { positive influence of trust towards } \\
\text { professional commitment }\end{array}$ \\
\hline $\begin{array}{c}\mathrm{X}_{1} \\
\text { towards } \\
\mathrm{X}_{2}\end{array}$ & $\rho_{12}=0,39$ & 5,62 & 1,97 & $\begin{array}{l}\mathrm{H}_{0} \text { rejected, } \mathrm{H}_{1} \text { accepted, there is a direct } \\
\text { positive influence of trust towards } \\
\text { empowerment }\end{array}$ \\
\hline
\end{tabular}

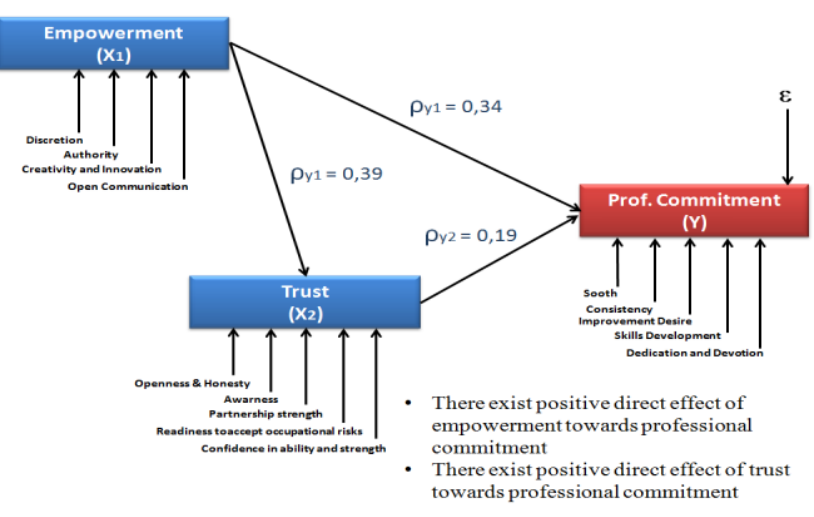

Figure 1. Problem constellation

To make a recommendation is used Sitorem analysis. Sitorem is a scientific introduction theory for conducting operations research in the field of management education. The results of the sitorem analysis can be seen in figure 2

The problem constellation can be described as follows :

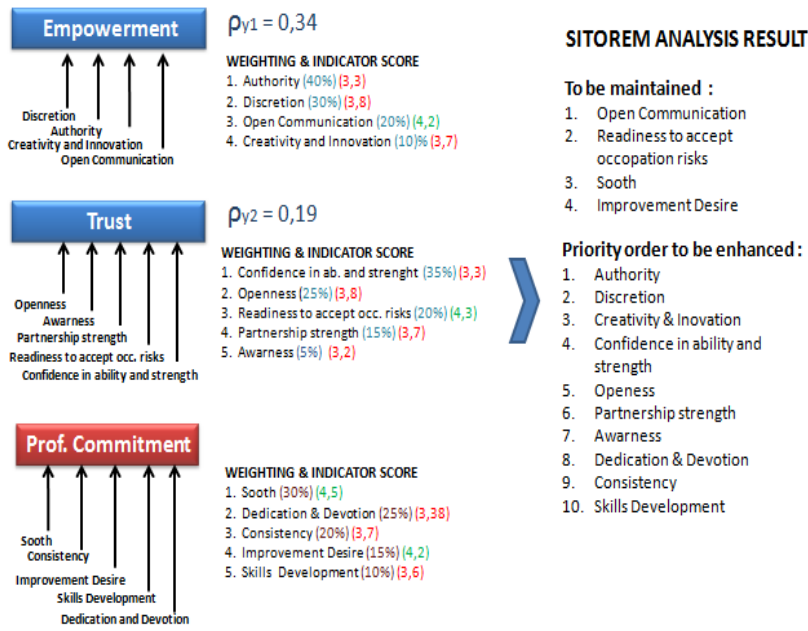

Figure 2: Sitorem analysis results

As stated by Hardhienata [11] Sitorem analysis considers three criteria, namely strength of influence between variables $(\rho)$, handling priority $(\%)$, and value of indicator (value). As can be seen in Figure 2 above, there are two groups of suggestions, which are suggestions for maintaining a well-defined indicator consisting of open communication, readiness to accept occupation risks, sooth, and improvement desire, and suggestions for improving indicators in order of priority improvements as follows: authority, confidence in ability and strength, discretion, openness, dedication and devotion, consistency, partnership strength, creativity and innovation, skills development, and awareness.

Published By:

Blue Eyes Intelligence Engineering \& Sciences Publication 


\section{CONCLUSION AND RECOMMENDATIONS}

From the above description can be summarized as follows: (a) there is a positive direct influence of empowerment to organizational commitment, (b) there is a positive direct effect of empowerment to organizational commitment, (c) there is a direct positive influence of trust on organizational commitment .

From Sitorem's analysis it is concluded that there is a preserved indicator, i.e. open communication, readiness to accept occupation risks, sooth, and improvement desire, and indicators that need to be improved in order of priority of treatment is as follows: 1 . authority, 2. discretion, 3. creativity and innovation, 4. confidence in ability and strength, 5. openness, 6. partnership strength, 7. awareness, 8. dedication and devotion, 9. consistency, 10. skills development.

To obtain a broader picture of the influence of other variables it is recommended to develop further research by examining the effect of other variables that have not been studied on professional commitment.

\section{REFERENCES}

1. Adrian Frunham, The Psychology of Behavior at Work, New York: Rouledge Press, Inc., 2011.

2. Blanchard, John Carlos dan W. Alan Randolph, Empowerment Takes More Than a Minute; Libatkan Setiap Karyawan Lejitkan Perusahaan Anda, Edisi Kedua, Alih Bahasa: Anik Soemarni, Surabaya: PT Maju insan Cemerlang, 2012.

3. Brick Jean. Academic Culture: A Student's Guide to Studying at University, Second Edition, Australia: Macmillan Publisher, 2011.

4. Colquitt,Jason A., Jeffery A. LePinedan Mixhael J. Wesson. Organizational Behavior: Improving Performance and Commitment in the Workplace, New York: McGraw-Hill Companies, 2009.

5. Fred Luthans, Organizational Behavior, New York: McGraw-Hill, 2008.

6. Frunham, Adrian. The Psychology of Behavior at Work, New York: Rouledge Press, Inc., 2011.

7. Fukuyama, Francis, Trust: The Social Virtues and The Creation of Prosperity, New York: Free Press Paperbacks, 1995.

8. George Jennifer M. George and Gareth R. Jones, Understanding and Managing Organizational Behaviour, Sixth Edition, New Jersey: Pearson Education, Inc. 2012.

9. Glickman, Carl D. Stephen P. Gordon, and Jovita M. Ross-Gordon, Supervision and Instructional Leadership: A Developmental Approach, 8th ed., Boston: Pearson Education, Inc., 2010.

10. Greenfield. Jr,A.C., Carolyn Strand Norman, dan Benson Wier. on Earnings Management Bahavior, Journal of Bisiness Ethics, 2008.

11. Hardhienata, S., 2017. The Development of Scientific Identification Theory to Conduct Operation Research in Education Management. IOP Conference Series: Materials Science and Engineering. Volume 166, 2017.

12. Heinz Weihrich dan Harold Koontz, Management: A Global Perspective, Elevent Edition, Singapore: McGraw-Hill Education (Asia), 2005.

13. Jennifer M. George and Gareth R. Jones, Understanding and Managing Organizational Behavior, Sixth Edition, New Jersey: Pearson Education, Inc. 2012

14. John. W. Newstorm, Organizational Behavior: Human Behavior at Work, New York McGraw-Hill Companies, Inc., 2011.

15. Judeh Mahfuz A.,"An Analysis of the Relationship between trust and Employee empowerment” International Business Management6(2). ISSN; 1993-5250,2012.

16. Kannan, R. and S. Muthu Perumal Pillai, An Examination on the Professional Commitment of Engineering College Teachers, Medwell Journal: International Business Management 2 (6): 218-224, 2008.

17. Kanooni, Armanm "The Employee Empowerment," Journal of Information Technology Departement, November7, Capella University, 2005.

18. Khan Sharafat, "The Key to Being a Leader Company: Empowerment". Journal for Quality and Participatio,1997.

19. Koppi, A.J., M.J. Chaloupka, R. Llewellyn, G. Cheney, S. Clarks, and
T. Feton-Kerr. Academic Culture, Flexibility and the National Teaching and Learning Database, Australia: New Technologies in Teaching and Learning, University of Sydney, 1998.

20. Langton, Nancy dan Stephen Robbins. Organizational Behavior: Concepts, Controversies Applications, Ontario, Canada: Pearson Education Inc.: 2007.

21. Laurie J.Mullins, Management and Organizational Behavior, Seventh Edition, England: Pearson Education Limited, 2005.

22. Luthans Fred, Organizational Behavior, New York: McGraw-Hill, 2008.

23. Lawrence J. Saha dan A. Gary Dworkin, International Handbook of Research of Teachers and Teaching, (New York: Springer Science Business Media, LLC., 2009).

24. Malik, Zaki dan Bouguettaya Athman. Trust Management for Service- Oriented Environments, London: Business Media, 2009.

25. M Jennifer M. George and Gareth R. Jones, Understanding and Managing Organizational Behaviour, Sixth Edition, New Jersey: Pearson Education, Inc. 2012.

26. McShane Steven L. and Mary Ann Von Glinow, Organizational Behaviour, 5th edition, New York: McGraw-Hill Irwin, 2010.

27. Merriman Jennifer, "Content Knowledge for Teaching: Framing Effective Professional Development”, Dalam Linda E. Martin, Sherry Kragler, Diana J. Quatroche, dan Kathryn L. Bauserman (Editor), Handbook of Professional Development in Education: Successful Models and Practices, PreK-12, New York: The Guiford Press, 2014.

28. Murphy Sean P. Academic Culture: Professional Preparation and the Teaching Life, New York: The Modern Language Association of America, 2008

29. Neil H. Snyder, James J. Dowd, Jr., and Dianne Morse Houghton, Vision, Values and Courage:Leadership for Quality Management, New York: The Press, 1994.

30. Pamela S. Shockley-Zalabak, Sherwyn P. Morreale, dan Michael Z., Building: The High-Trust Organization: Strategies for Supporting Five Key Dimensions of Trust, San Fransisco: Jossey-Bass, 2010.

31. Razak Nordin Abd, I Gusti Ngurah Darmawan dan John P. Keeves, "Teacher Commitment", dalam Lawrence J. Saha dan A. Gary Dworkin (Editors), International Handbook of Research on Teachers and Teaching, Part One, New York: Springer, 2009.

32. Raymond B.Fox,"The Committed Teacher", Nothern Illinois University: The Mc Graw - Hill, 2003.

33. Schermerhorn. John R, et al, Organizational Behavior, 11th edition, New York: John Wiley \& Sons (Asia) Pte. Ltd, 2011.

34. Shockley-Zalabak, Pamela S., Sherwyn P. Morreale, dan Michael Z. Building the High-Trust Organization: Strategies for Supporting Five Key Dimensions of Trust, San Fransisco: Jossey-Bass, 2010.

35. Slavin Robert E.. Psikologi Pendidikan: Teori dan Praktik, Edis Kedelapan, Jilid ke-2, Terjemahan: Marianto Samosir, Jakarta: PT Indeks, 2009

36. Snyder, Neil H. James J. Dowd, Jr., and Dianne Morse Houghton, Vision, Values, and Courage: Leadership for Quality Management. New York: The Free Press, 1994.

37. Zaki Malik dan Athman Bouguettaya, Trust Management for Service: Oriented Environments, (London: Business Media,2009). 